\title{
Women under Patriarchy: A Postcolonial Feminist Critique of Wole Soyinka's The Lion and the Jewel
}

\author{
Dr. Ramesh Prasad Adhikary, \\ Assistant Professor, Tribhuwan University, \\ Kathmandu, M.M. Campus, Nepalgunj, Nepal
}

Doi:10.19044/esj.2020.v16n14p89 ～URL:http://dx.doi.org/10.19044/esj.2020.v16n14p89

\begin{abstract}
This research paper is focused on the exploration of female exploitation in Wole Soyinka's The Lion and the Jewel in the context of postcolonial Nigeria. This paper tries to explore how Wole Soyinka posits postcolonial and feminist rebellion in his play. It explores female suppression and also depicts the failure of postcolonial and feminist resistance to colonial principles. Like colonialists, postcolonialists and feminists overlook the different kinds of injustice and harassments women undergo in the nonWestern world, which is also called the Third World. The text also shows how the female suppression and exploitation continues even after the abolition of colonial rule in Nigeria. The researcher has taken the text The Lion and The Jewel of Soyinka as a primary source of data for the qualitative research; and the postcolonial feminism has been used as a theoretical tool for the analysis of the text.
\end{abstract}

Keywords: Colonialism, postcolonialism, feminism, suppression, resistance

\section{Introduction}

Wole Soyika is one of the most imaginative writer of the African continent and the supporter of native culture of Nigeria a multi-cultural, multireligious and multi-lingual country. Despite distinct varieties of indigenous cultures, the influences of Western culture and Christianity become visible in various forms after the advent of colonialism in Nigeria to which Soyinka's family was no exception. His grandfather belonged to indigenous, Yoruba tribe but his parents were Christians but his parents were Christians reflecting colonial influence. His mother was a devout Christian and father, the head master of a village school established by Britons.

In the surface reading, The Lion and the Jewel (1959) is a comedy filled with joyous excitement. It is crafted with the problems and impacts of colonialism in the Third World countries especially Nigeria. In the play, a 
young West-educated and oriented school teacher, Lakunle, spreads and nurses colonial civilization mostly on female figures like Sidi and Sadiku. Sidi becomes a complete victim of patriarchy. So also Sadiku has become at the hands of Baroka, a patriarchal representative figure

Lakunle, had better bookish knowledge but he didn't know how to use words to attract the 'Jewel' of the Yoruba village. He tries to woo Sidi all the time. He also points out her messy behavior so as to arouse the sense of the need of a condescending figure. Although Lakunle does not make any such physical assault on Sidi, he severely tortures her psychologically through his colonial supremacy.

The beautiful lady slips from his hand. He is smart enough to have multiple wives, which is a tradition of Okiki Family. This family is taken as the Lion family which devours all the elegant women and weaklings of society. Sidi becomes aware of her remarkable beauty after a foreigner takes her photos and publishes it abroad. She tries to exhibit her coquettish power before Bale, but his sexual inability is used as a trap to cage her. Her refusal to marry him is clear in her words and activities. But ironically, she is seduced and compelled to become his wife. Sidi becomes ready to marry an old man because of her tradition which does not permit a girl to marry another person after being seduced by one. In this respect, she forgives the rapist rather than taking any legal action against him. But she was afraid of Lakunle's proposal only because he is against the custom of paying bride-price. In these steps she is advocating her own culture. As a traditional native girl she does not cross the boundary set up by her patriarchal society. Thus, the Lion (the Bale) obtains his prize, the Jewel (Sidi) and at the same time his utterance of a proverb that he likes "new wine in old bottle" implies that he wants to control and prevent young principles of woman and of neo-colonial civilization. It shows Baroka's positing of himself above the law and morality. Rather he goes seducing girls whom he likes.

Sidi and Sadiku are major female characters in the play and are the independent subjects of the post-colonial Nigeria. But they are victimized by Lakunle and Baroka. Lakunle, desired to win the heart of Sidi, a beautiful lady of the same age. He praises her beauty and intelligence so as to arouse the sense of need of a superior figure. Baroka, an old Bale of Ilujinle of 62, has a tendency of having multiple wives, intentionally seduces Sidi, and ultimately compels her to become his wife. At the same time the society celebrates this monstrous act according to their rituals. Patriarchal and male supremacy of their tradition was manifested as the abuse of female rights and sexuality.

After a great political change and freedom of Nigeria from colonial power, women of Nigeria have more pathetic situation about their sexuality and other social rights. The culture of domination shifts from the hand of colonialism to patriarchy. It shows that the official announcement of 
independence of Nigeria, does not completely end at colonial principles. Since there is no direct presence of colonial agent after decolonization, the culture to oppress women remains patriarchal

\section{Objective of the Study}

The major objective of this research was to investigate how the females were exploited in the independent Nigeria through the analysis of Wole Soyinka's play The Lion and The Jewel. This researcher aims to portray how the so called male supremacy is projected in the play even in the post-colonial Nigeria.

\section{Delimitation of the Study}

This research is limited to the analysis of Wole Soyinka's play, The Lion and The Jewel rom the prespective of postcolonial feminism. It is focused on how the patriarchal tradition was prevalent in Nigeria even after they got the political freedom from colonial power.

\section{Review of Related Literature}

From its release, the play has been interpreted from various perspectives by different critics. Some critics say that Lakunle's rejection of bride-price is not his modern thought. They say it was his strong economic problem that he simply cannot afford it.

In this context, the critic Kronfield (1975) says, "His rejection of traditional custom has an economic cause that he simply cannot afford" (205). Next Jacobus says, "The play makes clear antithesis between the western modernization and the tradition by offering "a comic view of Nigerian attitudes toward European values" (1175). Lakunle follows the culture of the colonizers and so, he is caught up in a state of "neither the one nor the other" (Bhabha 219) and lies in its concealment behind its masks.

Morrison (1998) presents about Soyinka's text: "The Interpreters is as an attempt to capture particular moment in the lives of a generation which was trying to find its feet after independence" (qut. in Morrison 753). It can also be inferred that he has deliberately given the very resolution to many of his works as a panacea for post-colonial multiple identities

Postcolonial feminism presents its different ideas than the Western feminism or the classical feminism.

The situations of the women of the different parts of the world differ vastly even after the decolonization of non-Western countries. Postcolonial and feminist criticisms failed to counter the colonial or imperial and patriarchal atrocity and biasness for the recognition and representation of the different variants of national and the societal classes. Consequently their 
attempt remains unproductive and ineffective so as to devoid the prevalent prejudices and injustices over the classes in the post-colonial countries.

No one has critically analyzed the text from the concept of female suppression. So the researcher takes the venture to expose the underlying evils that assist female suppression even in an independent country like Nigeria.

\section{Theoretical Framework: Postcolonial Feminism}

Postcolonial feminism is an exploration of the mixture of colonialism and neocolonialism. It focuses on gender, nation, class, race, and sexualities in the different contexts of women's lives, their subjectivities, work, sexuality, and rights. It can be included into cultural studies too. It is also the voice of feminists of Third World origin located in the metropolitan university. Their aim was to define a recognizable postcolonial feminism.

In 1980s, postcolonial feminist critics like Hazel Carby, Chandra Talpade Mohanty, and Suleri crititicized Western feminists because they have a history of universalizing women's issues. Western feminism defined 'women' by their gender and not by social classes and ethnicity. Postcolonial feminist critics blamed that mainstream Western feminists ignored the voices of nonwhite, non-Western women for many years, thus creating resentment from feminists in developing nations.

Gandhi in Postcolonial Theory: A Critical Introduction (1998) posits that both feminism and postcolonialism have similar theoretical route, but postcolonial and feminist theory occurs from the study of the Third World woman. Therefore, the relation of race and gender shows the Third World woman with a stereotype which is almost too good to be true. Gandhi (1998) further says:

Marginal/subjugated has helped reform the aggressive canonicity of high Western culture. And yet, even as the margins thicken with political significance, there are two problems which must give pause. First, as Spivak (2006) insists, the prescription of non-Western alterity as a tonic for the ill health of Western culture heralds the perpetration of a new orientalism. Second, the metropolitan demand for marginality is also troublingly a command which consolidates and names the non- West as interminably marginal. (85)

Thus, the Third World becomes a stable metaphor for the minor zone of nonculture and underdevelopment and its value inheres only in its capacity to politicize or- predictably- subvert major, that is to say, more developed, cultural formation.

Suleri (2006) says that the linking of the term 'postcolonial' with women, however, almost inevitably leads to the simplicities that underline 
unthinking celebrations of oppression, elevating the racially female voice into a metaphor for 'the good'. She sees the similar essentialist move in overemphasis of postcolonial feminist's racial aspect of female. "This essentialist metaphoricity impedes a reading that attempts to look beyond obvious questions of good and evil" (337) and at same time postcolonial feminism, Suleri says, "cannot escape bewilderment in the act of prioritizing gender/race" (337). This implies that it has been a challenge for postcolonial feminism to get rid of similar mistake that postcolonialism and feminism committed.

Spivak (2006) feels unfortunate when feminist criticism reproduces the axiom of imperialism and forwards the following opinion about the 'worlding' of what is now called the Third World, in her essay "Three Women's Texts and a Critique of Imperialism":

To consider the Third World as distant cultures, exploited but with rich intact literary heritages waiting to be recovered, interpreted, and curricularized in English translation fosters the emergence of Third World as a signifier that allows us to forget that 'worlding', even as it expands the empire of the literary discipline. (269)

Here we find Western feminism putting on colonial motive of alterity that is to create a marginal group so as to set up itself as center. In this respect, Mohanty (2006), criticizes: "The discursively consensual homogeneity of 'women' as a group is mistaken for the historically specific material reality of a group of women" (qtd. in Aschroft 103).

In the essay "Mapping the Colonial Body: Sexual Economies and the State in Colonial India", Price and Shildrick (1995) posits:

Why it should be the gendered female rather than the male body which provides the prime, although by no means exclusive, site of regulatory practices? As women are always already in a different relation to their bodies as sexed, not in the sense of that being the source of rigid givens, but in the sense that there is an overlap but never identity between the lived experience of women and men. (389)

Thus, this discipline or a sect of feminism urges to form different space for a radical politics of culture, one differentiated from both right and leftwing articulations of culture and nationalism. There is of course abundant evidence of native dissatisfaction and dissent under colonial rule, of contestation and struggle against diverse forms of institutional and ideological domination. "Inscriptions and signs of resistance are discernable in official 
archives and informal texts". In "Contemporary Postcolonial Theory: A Reader", Parry (2006) says: "Traces of popular disobedience can also be recuperated from unwritten symbolic and symptomatic practices in which a rejection or violation of the subject positions assigned by colonialism is registered" ( 85).

In the play a young school teacher, Lakunle, educated in western thought, spreads and nurtures colonial policies mostly on female figure like Sidi and Sadiku. Sidi become a complete victim of patriarchy. But Sadiku has become a victim from the very beginning of the play at the hands of Baroka, a patriarchal representative figure.

\section{Textual Analysis: Postcolonial Feminism}

The analysis of text, The Lion and the Jewel presents traditional dependence of female figure, Sidi, a young beautiful girl (the Jewel), on the tradition. It also presents Lakunle, a follower of colonial principles; and Baroka, an icon of patriarchy. Baroka, the Bale of 63 of Ilujinle society, even after his unjust and unlawful seduction of Sidi boastfully presents himself as respected personality in the society. Both of them show their consent to the tradition of Ilujinle society by keeping mum against Baroka's forceful seduction. The whole society too authenticates the patriarchal normativity by holding a ceremony in favour of Baroka. It shows how the females were exploited in post-colonial Nigeria as a colonial refuge to patriarchy.

Lakunle is the representative of colonial power as he imitates their method of eating, way of living, and the ideology in the play from the very beginning. Lakunle took a pail from the hand of Sidi. It shows how contradictory face of colonizing figure longs to fulfill its sexual need through use of vulgar words. The sexist exclusivity of these discourses (man, mankind, etc.) demonstrates their ideological alliance with patriarchal practices. However, Lakunle does not walk behind to save himself from the offence. He attacks Sidi's gender but does not care what other people say about him. It shows his failure to protect himself as a colonialist figure. Instead, he takes defense from patriarchy where women remain not in the state to make arguments against male superiority.

There is a custom of paying bride-price in Nigeria. It means the girl is chaste or has not had any earlier sexual relationship. But Lakunle is against that custom: "A savage custom, barbaric, out-dated, rejected denounced, accursed, excommunicated, archaic, degrading, humiliating, unspeakable, redundant, retrogressive, remarkable, unpalatable" (8). His idea about marriage seems quite modern: "I want to wed because I love; I seek a lifecompanion [to] be together as one flesh. Sidi, I seek a friend in need/An equal partner in my race of life" (9). But Sidi puts her position by urging the postcolonial subjects to initiate action in engaging or resisting imperial power. She 
states her determined condition that Lakunle has to pay bride-price at any cost if he wants to have her as wife. Lakunle also takes support of feministic idea to counter some of the customs that to have their origin in some patriarchal notion. He opines on bride-price: "To pay the price would be to buy a heifer off the market stall" (9).

Lakunle forces Sidi to be modern and he thinks that to have an open kiss is to become modern: "Be a modern wife, look me in the eye and give me a little kiss-- like this (kisses her)" (10). Moreover he says, "Bush girl you are, bush girl you'll always be; Uncivilized and primitive/bush girl! I kissed you as all educated men and Christians [...] kiss their wives/It is the way of civilized romance" (10). He gives a quite narrow definition of 'educated people and romance' that they are free to do anything they like because they are educated or they are allowed to do so by law. Lakunl defines romance "the sweetening of the soul with fragrance offered by the stricken heart' (10). It implies that he has the privilege to define every abstract aspect of human discourse but at the same time it is a strategic step to terminate traditional value that operates against colonial perpetration.

A group of village girls expresses their view on the magazine from a stanger. It comprises many photos, among the photos, Sidi's photos are exquisitely beautiful and angelic. This scene of women's views on their beauty exposes the women psyche out as the second girl opines on the photo that Baroka's photo does not match with his social position and power: "His image is in a little corner somewhere in the book and even that corner he shares with one of the village latrines" (12). Sidi makes a comparison between their photos and comes to a conclusion: "If that is true, then I am more esteemed than Bale Baroka, the Lion of Ilujinle. This means that I am greater than the Fox of the undergrowth, the living god among men" (12). It is the self- assertion of women's beauty that wants to resist the identity given by male.

Not only Baroka but also his presence on the stage shows his boastful masculinity "Yes, ... it is five full months since last I took wife for five full months" (18). It implies even his five months gap to bring another wife has been ages for him and after the evaluation of the photograph he reaches at a decision that would make Sidi his next wife.

Even the interior feelings of their sex becomes irrational to other women like Sadiku. She thinks angry god has taken hold of her mind and says of Sidi: "For most surely some angry god has taken possession of you" (22). It is because Sadiku has modulated her understanding on the premises of patriarchy though she is female by sex. Here acquired understanding of gender is operative rather than her conception from similar sex. That is why Sidi views Baroka's harsh masculinity as cruelty but for Sadiku it is an opportunity which gets illuminated in Sidi's comment on his nature. 
Baroka's furious remark describes how male cannot bear the words of their being old from a young girl: "She says ... that I am old that I am much too old? Did a slight unripened girl say this of me?" (26). These words of Sidi become very powerful as it does not match with the wild aspiration of masculinity. He weaves a snare, pretending of being lost in complete disappointment of his waning virility or climacteric physics and uses his wife Sadiku to play a role. Baroka clarifies why he has been so despondent and implies that he failed to carry on his sexual roles and responsibility.

Here, women's protest is against patriarchal pride of their sexual potency. But it is the day Barokas' impotency is revealed to his wife Sadiku and women enjoy this day as their victory because they think it is they who sucked him out. Sadiku says to Lakunle, "You a man? Is Baroka not more of a man than you? And if he is no longer a man, then what are you? [Lakunle, understanding the meaning, stands rooted, shocked.] Come on, Dear girl; let him look on if he will. After all, only men are barred from watching this ceremony" (32). Sadiku takes Baroka's drying out as the celebration of their victory. It is a great challenge to the colonial representative to hold his position of a reformer, but has to protect another faculty that is of male, and Sadiku enforces him. After knowing the secret of Baroka's sexuality, Sidi goes to vex him and make an offence of his impotency. Sidi offences him on his favorite's deserting and inquires: "Is her dissatisfaction with her lord and husband?" (38). Retorting this insult, Baroka, in a very challenging tone, warns to test it: "Try, if you can make me feel a humorless old ram. I allow no one to watch my daily exercise, but as we say, the woman gets lost in the woods one day and every deity dies the next" (38).

Lakunle bitterly criticises Baroka's odious act of molestation and Sadiku's abetment in the act. She has the courage to put her hand into his pocket to seize his money so as to make him spend it for the celebration of Sidi's sexual involvement with Baroka. Although Lakunle is a male figure like Baroka, he hates the way Baroka behaves with women and has sexual relationship: "Baroka is a creature of the wilds, untutored, mannerless, devoid of grace"(52). This is a typical colonial view of non-Western representative.

Lakunle tries to posit how Baroka seduced her and claims that he can hear this in very determined way: "Tell me the worst; I'll take it like a man. Is it the fright which affects you so, or did he?" (53).

Sadiku to consol Sidi, as: "Too late for prayers. Cheer up. It happens to the best of us" (53). These words pronounce how weak are the women of that society to take any action against Baroka's vicious act of Seduction. Law and religion formed to protect rights of common people but they are used to benefit for a certain powerful people. Lakunle wants to take advantage of the victim of patriarchy by showing the fear that Sidi is no longer a virgin to be paid bride-price. It means he can marry her without bride-price but when 
situation comes in his favor he expresses his dilemma to postpone it as: "Surely she can wait a day or two at least. There is the asking to be done, and then I have to hire a praise-singer, and such a number of ceremonies must firstly be performed" (55). By now he is paying no heed towards the victimized to protect her from being insulted in the society. It means Lakunle also wanted to have only a sexual relation with her. But after the break down of her virginity he no longer wants to marry her. After all, Sidi makes her mind to wed Baroka. From the analysis of the text, it is to claim that the playwright advocates his tradition and culture of the past.

\section{Conclusion}

In conclusion, this researcher concludes that there was the female suppression in Wole Soyinka's The Lion and the Jewel in the context of postcolonial Nigeria. It also shows the failure of postcolonial feminist to counter colonial principles. Like colonialists, The play depicts the picture of the postcolonial Nigeria where women even after their political independence suffer from similar harassment and sexual abuses. It also presents the problems and impacts of colonialism in African countries like Nigeria. The present study has revealed that the exploitation of patriarchy is continuing in the postcolonial phase of Nigeria. It also shows how female undergo double suppression by 'colonialism' and 'patriarchy'. For that reason conflicts appear in the society among such opposing forces and factors.

\section{References:}

1. Bhabha, H. K. (1993). The Location of Culture. London: Routeldge.

2. Gandhi, L. (1998). "Postcolonialism and Feminism". Postcoonial Theory: A Critical Introduction. New York: Columbia UP, pp. 81-102.

3. Jacobus, L. A. (1993). "Introduction". The Bedford Introduction to Drama. 4th ed. Ed. Lee A Jacobus. Boston: Belford.

4. Kronfield, J. Z. (1975) "The Communalistic African and the Individualistic Westerner." Research in African Literature 6, pp. 199225.

5. Mohanty, C. T. (2006). "Under Western Eyes: Feminist Scholarship and Colonial Discourses". Contemporary Postcolonial Theory: A Reader. 4th ed. Ed. Padmini Mongia. New Delhi: OUP. Pp. 172-97.

6. Morrison, K. 'The Second Sex on Vision of Horror in Wole Soyinka's The Interpreters". Black American Literary Forum 22.4 (Winter): pp. 753-65

7. Parry, B. (2006). Resistance Theory/ Theorising Resistance or Two Cheers for Nativism". Contemporary Postcolonial Theory: A Reader. 4th ed. Ed. Padmini Mongia. New Delhi: OUP, pp. 84-109. 
8. Price, J., and Margarit Shildrick. (1995). "Mapping the Colonial Body". Gender and Colonialism. Eds. T. Foley et al. Galway: Galway UP, pp. 388-98.

9. Soyinka, W. (1963). The Lion and the Jewel. Collected Plays.Vol. 2. New York: Oxford University Press, pp. 3-58.

10. Spivak, G. C. ( 2006). "Poststructuralism, Marginality, Postcoloniality and Value". Contemporary Postcolonial Theory: A Reader. 4th ed. Ed. Padmini Mongia. New Delhi: OUP, pp.198-222.

11. Suleri, S.(2006). "Woman Skin Deep: Feminism and the Postcolonial Condition". Contemporary Postcolonial Theory: A Reader. 4th ed. Ed. Padmini Mongia. New Delhi: OUP, pp. 335-46. 